\title{
Measuring the Effect of Cognitive and Metacognitive Questioning Strategies on EFL Learners' Reading Comprehension in Understanding, Critical Thinking and the Quality of Schema at the University of Hail-KSA
}

\author{
Lina A. Salameh ${ }^{1}$, Zakaria A. Salameh ${ }^{1} \&$ Aida H. Al-Emami ${ }^{1}$ \\ ${ }^{1}$ Department of English, Faculty of Arts, University of Hail, Saudi Arabia \\ Correspondence: Lina A. Salameh, PO Box: -2152-, City of Hail, Saudi Arabia. E-mail: \\ linabanisalameh@yahoo.com
}

Received: April 29, 2019 Accepted: June 17, 2019 Online Published: July 18, 2019

doi:10.5539/ijel.v9n5p12 URL: https://doi.org/10.5539/ijel.v9n5p12

\begin{abstract}
It was found out that the cognitive and the metacognitive strategies which enable students to use their prior knowledge or schemata increase the level of students' engagement in the learning process and thus stimulate their critical thinking and a greater awareness of other perspectives in reading. Therefore, this study which is based on the main principles of the schema theory aims at training EFL learners at the University of Hail on making connections between their prior knowledge and the reading text to improve students' understanding, critical thinking, and the quality of schema. Five questioning strategies were incorporated to make training more effective: KWL, questioning the author, self-questioning, guided questions, and making connections strategy such as self-to text connections, text-to text connections and text to world connections. The sample of the study consists of two groups: experimental and control. A schema-based test was designed to measure the students' achievement before and after the experiment. The results then were analyzed by t-test. It was found out that the type of instruction that students receive affects reading comprehension. And thus, teaching students to use cognitive and metacognitive strategies enables effective reading comprehension.
\end{abstract}

Keywords: schema theory, cognitive and metacognitive, KWL strategy, questioning the author, self-questioning, guided questions, making connections, critical thinking, quality of schema

\section{Introduction}

Eggen and Kaucbak (1995) pointed out that the first reason for shedding light on metacognition by language theoreticians and researchers was that metacognitive knowledge develops skilled thinkers and sustainable learning. The second reason was the integration between metacognition and language teaching which has the potential of founding self-dependent learners (Bonds \& Peach, 1992; Garb, 2000). Devine (1993) identified the third reason as the ability of metacognition to play a significant role in language learning as it covers three main kinds of knowledge which include knowledge of one's self, the tasks at hand, and the strategies we use. Kendeou (2014) mentioned that reading comprehension consists of use of language, reflection of what they learn and engagement in writing assignments. Iannelli (2016) argued that catering for learners' metacognitive awareness of strategies in reading will guide the readers to self-awareness of their understanding before, during and after reading. Francois (2016) explained that internal processing in reading tasks leads to improve metacognitive knowledge to choose among methods to help in comprehension.

Hazzard (2016) pointed out that the potential to read is important in both study and life in general. Hence, EFL learners should be trained to be able to gain the needed knowledge to satisfy their needs.

Yang (2002) explained that reading the text by the reader can be described as processing of words, phrases, sentences and paragraph. This way of processing is considered as a method to measure the cognition of understanding which comes in various stages and that comes only at lexical and syntactic levels. Dole, Duffy, Roehler, and Pearson (1991) considered learners' interferences in reading as the base of the comprehension process. Devine (1986) assured that using prior knowledge would cater for such interferences. Thus, this would help learners make their own interpretations through activating their schemata. On the other hand, critical thinking 
is considered as another main skill in metacognition that contributes to reading comprehension. Thus, Norris and Phillips (1987) assured that reading is thinking more than reading what is written. Ruggiero (1984) and Becky (1989) also referred to this assumption as reasoning in reading. Broek and Kremer (2000) claimed that the success of reading comprehension depends on both the quality and the type of schemata involved. Rumelhart (1980) and Marshall (1995) pointed out that schemata consist of related responses and items which depend on both external knowledge and mental associations between terms known as the quality of schemata. Therefore, the researcher in this study determined students' quality of schema by: a) students' schematic representation of the core ideas in the text and b) students' schematic connections (e.g., text to life, text to text and text to world connections).

Many educationalists and practitioners support the idea of teaching students cognitive and metacognitive strategies in order to enhance learners' schemata before reading. An example on this is reading headings and the titles and make predictions, semantic maps, pre-reading strategies, self-questioning, questioning the author, KWL strategy, making connections, etc. (Kirschner, Sweller, \& Clark, 2006; Mayer, 2004).

In Saudi Arabia, EFL learners' level in reading achievement has been reported to be of low quality based on the researchers' long experience in the field of teaching reading. Moreover, many of the instructors at universities presuppose that university students are mature enough to pick up the meaning while reading. Therefore, they ignore teaching them the effective strategies and focus only on just extracting answers to their questions. Accordingly, many EFL learners struggle with the reading texts in an attempt to achieve comprehension. Therefore, they start to focus on words, grammar, and sentence structure. They have no minimum knowledge about the importance of owning strategies that may pave the way to achieve comprehension in addition to the ignorance of the prominent role of their prior knowledge they possess in interpreting the reading text.

Therefore, this study is an attempt to measure the effect of the cognitive and the metacognitive Questioning Strategies (QS) on improving the performance of EFL learners' reading comprehension at the University of Hail (UOH) in: a) understanding, b) critical thinking, and c) the quality of schema. Accordingly, the researchers used five incorporated strategies: KWL, questioning the author, self-questioning, guided questions, and making connections strategy such as self-to text connections, text-to text connections and text to world connections. They were used according to the three-phase approach (before, during, and after reading). This study is an attempt to empower students to use reading comprehension strategies that best enable them to create a metacognitive awareness through creating bridges between their existing knowledge (schemata) and the new knowledge they receive to move beyond literal recall.

\section{Review of Literature}

Most of teachers at schools in KSA focused their efforts on helping students at school level to use some reading strategies based on the fact that school stage is a preliminary step toward university stage. Accordingly, when students reach the university level, it is supposed that they already own the effective tools which they were taught at schools that enable them to catch up the meaning. But this is not always the case, university students still need to be guided and encouraged to use strategies when teaching reading taking into consideration their different abilities. For the researchers' knowledge, there are a few researches and attention paid to teaching university students how to make use of the reading strategies in KSA. Therefore, it is very important for university instructors who teach English reading courses to cultivate college students into strategic readers by teaching them how and what type of strategies to use. In this study, the researchers used questioning strategy with five incorporated strategies to teach EFL learners reading in the three selected skills: Understanding, critical thinking, and the quality of schema.

Questioning strategies are mainly emphasized by the metacognitive theory, the active processing theory and the schema theory. Firstly, the metacognitive theory suggests that self-questioning; for example, reflects learners' metacognitive awareness since it enables them to regulate their learning before, during and after reading (Peverly, Brobst, \& Morris, 2002; Hoyt \& Sorensen, 2001). Secondly, the active processing theory suggests that what the readers bring to the text from their prior knowledge is rather more important than the cues in the text (Davis \& Linn, 2000). The active processing of the text main concepts provides learners with deep understanding of the text and more connections to one's prior knowledge and experiences. It also helps learners make inferences and integrate information. It is concluded that questioning strategies, according to the active processing theory, are tools for activating students' background experiences because when students ask their own questions they are actively involved in processing the text main information (Ormrod, 2008). Thirdly, Schema theory proposes that every act of comprehension reflects one's knowledge of the world (Marshall, 1995; Rumelhart,1980).

Researchers in the field of teaching reading pointed out that when students wonder about the topic and make questions in reference to that topic, this will lead to more active processing of the text and thus more 
comprehension. For example, asking questions enables learners to create connections among the main components of the text, hypothesize and test hypotheses, focus on details, and reach out conclusions (Van den Broek, Tzeng, Risden, Trabasso, \& Basche, 2001). Bernadowski (2006) explored how the intervention staff development strategy, questioning the author, resulted in an increased ability of teachers to ask questions that stimulate higher engagement with the reading text. And, the increase in text engagement resulted in higher levels of comprehension. Therrien and Hughes (2008) referred to some approaches that assist readers to put together the main components within the passage, make connections between the information of the passage and their own prior knowledge, and control their understanding while reading; such as, text comprehension strategies. Similar studies investigated that using questioning strategies at all grade levels may help activate students' schemata (prior knowledge) and students were successful in using purpose questions to activate background knowledge and make predictions in passage content (Boulware-Gooden, Carreker, Thornhill, \& Joshi, 2007); Taboada \& Guthrie, 2006; Rowe \& Rayford, 2003). A study conducted by McCollister and Sayler (2010) on using questioning techniques by teachers indicated that questioning strategies enable students to engage in metacognition and enhance activities that students need to evaluate knowledge by collecting and analyzing data and not memorizing and recalling facts. More recent studies found out that teaching and implementing metacognitive strategies in reading enhanced students' concentration in the reading content, in planning and in selecting other characteristics that could help them formulate their tentative ideas. Moreover, using metacognitive strategies with students increased learners' motivation in learning and their knowledge both in problem solving and in evaluation (Usman, Aziz, \& Absida, 2017; Iannelli, 2016; Memiş \& Bozkurt, 2013).

Rouse (2014) investigated the effects of a self-questioning strategy on the comprehension of expository passages by elementary students in reading comprehension. Rouse concluded that self-questioning strategy with a fading prompt procedure was successful in increasing the reading comprehension of at-risk learners, and can be used with a variety of genres. Also, Sencebaugh and Sencebaugh (2015) conducted a study on the efficacy of systematic explicit instruction of a questioning strategy in enhancing the text comprehension of learners. The findings of the study revealed that questioning strategy enhanced reading achievement in the narrative texts. More studies conducted in the field of reading, indicated that those instructional strategies which stimulate learners' higher levels of thinking like questioning strategies have been found to be successful in improving critical thinking skills. This is done through enhancing students' thought below the surface of things to push them to deal with more complex content (Marzuki, Alim, \& Wekke, 2017; Samelian, 2017; Rashid \& Qaisar, 2016; Lewis, 2015; Feng, 2013).

According to Peterson and Taylor (2012) and Byrne (2011), students will meaningfully make use of questions through their prior knowledge. Nappi (2017) pointed out that designing questions based on the different cognitive taxonomies will generate questions requiring the various stages of remembering, analyzing, application and creation. Thus, using the concept of metacognition has the potential to enable students to thorough understanding. It is concluded that using this type of questions significantly contributed to achieving efficient teaching. On the other hand, even though the questions used are significant, they lack examination and measurement with regard to the content specified. Moreover, these questions are not properly connected to the knowledge of the text. Subsequently, there is a need to shed light on both the conceptual complexity of the questions asked by students and the connections between these questions and conceptual knowledge designed based on text. This approach could pave the way for processing as well as investigating studies on students' questions (Ajideh, 2003; Bransford, Brown, \& Cocking, 1999). The subject matter here is enhancing reading comprehension and knowledge based on questioning. Henceforth, the schema theory provides the concept of using questioning strategies which may be the first stage towards reading comprehension.

Based on the literature review, it is concluded that schema theory has the following characteristics. First, it could help students clarify how various types of knowledge are acquired. Second, it provides learning methods that are suitable for different types of knowledge. Therefore, comprehension and retention are improved through using such strategies which associate the text itself with students' background knowledge. Thus, the interaction of the reader's schemata with the text along with cognitive and metacognitive components is interrelated to help the reader reach meaningful understanding from the reading text. Moreover, the above review clarified the connections between metacognition, critical thinking and reading comprehension. This connection can be figured out through the characteristics of awareness and control that help readers choose and apply the reading strategies. Accordingly, the first researcher in this study designed the RCEM model (Reading Comprehension Enhancement Model) which may provide an insight towards an understanding of better reading comprehension instruction. The RECM model involved: (1) training students in cognitive and metacognitive questioning strategies that help them to actively use their prior knowledge and (2) training students to be actively engaged 
with the text. To achieve the objective of this study, students will be taught three skills: a) understanding, b) critical thinking, and c) the quality of schema. Based on the system theory (Von Bertalanffy, 1962), Figure 1 represents the conceptual framework of this study.

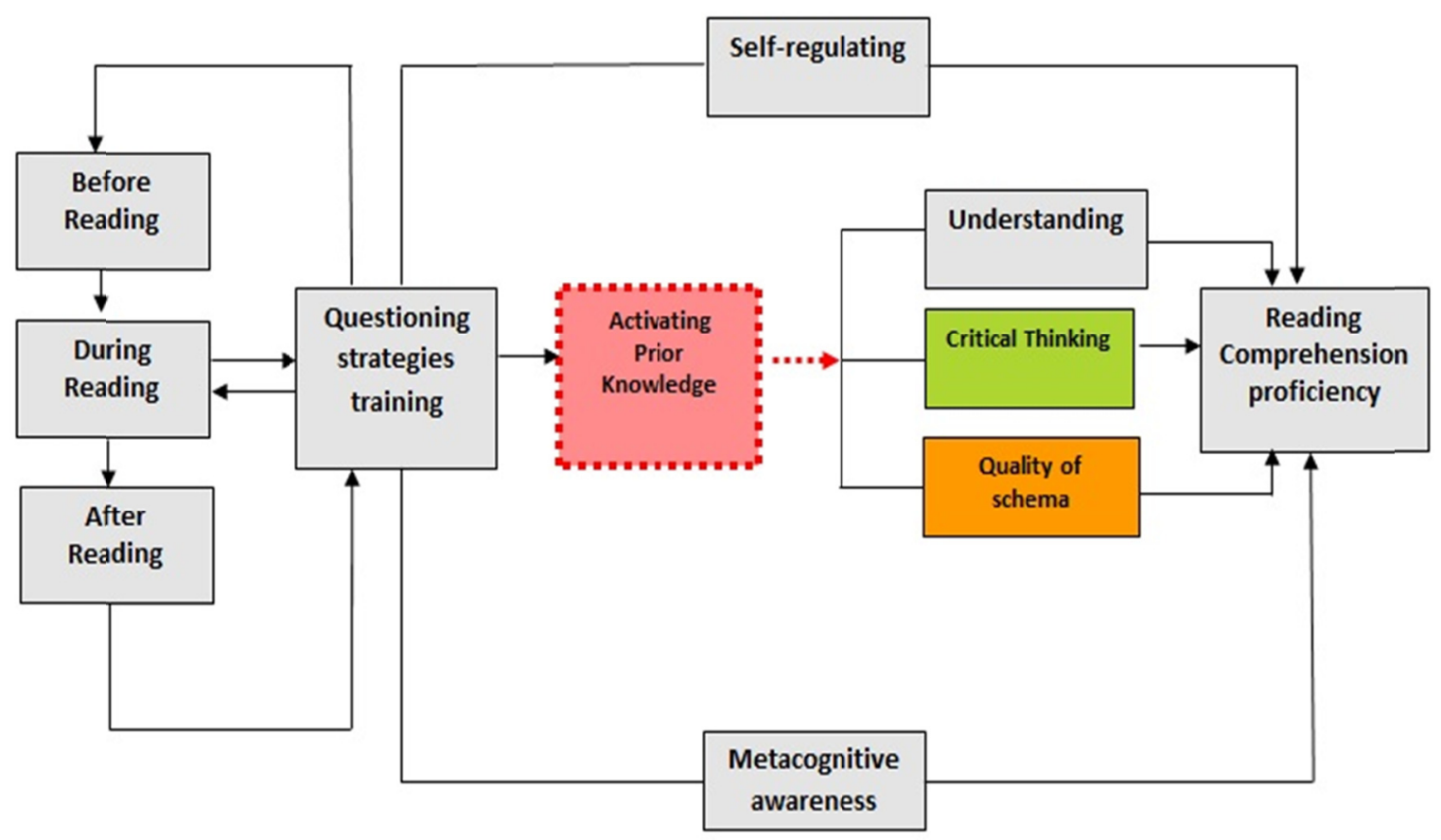

Figure 1. Reading comprehension enhancement model by Lina Salameh

\subsection{Rationale for Choosing the Five Questioning Strategies}

\section{$2.1 .1 \mathrm{KWL}$}

Tierney and Readence (2000) referred to it as a metacognitive strategy that was firstly created by Donna Ogle. It is a three-column chart that helps capture the before, during, and after components of reading a text selection. The reason to do the $\mathbf{K}$ column means what students know about the topic. $\mathbf{W}$ stands for Will or Want to know. L stands for Learned. They reiterated that every student uses his schema which is a framework for how they view the world. They asserted that accessing a students' prior knowledge is the first step towards integrating new concepts into their existing schema. Thus, KWL strategy helps activate the background knowledge and it is a good chance for students to define their aims.

\subsubsection{Directed-Reading Strategy}

Crane, Poziemsk and Gustafson (1998) pointed out that using direct-instruction of reading strategies may enhance student's self-concept and thus their control of reading process. Therefore, students need to be exposed to more meaningful contexts and purposes. This strategy is privileged in the sense that it can be used before, during and after reading. Using this strategy before reading is a) to help learners elicit their prior knowledge about the text's core ideas, b) build up connections between what they know and the subject of the reading text. It is used during reading in order to make comparisons and generalizations, set the theme and elucidate the meaning. After reading, it is used to reinforce the understanding, make connections, develop students' ways of thinking, organize the ideas in the text, think critically and build awareness of the main themes and structures (Harvey \& Goudvis, 2002).

\subsubsection{Self-Questioning Strategy}

It is a metacognitive and interactive reading strategy. It is used to help learners direct their own reading, ask themselves questions and read to find the answers (Morgan \& Saxton, 2001). In this study, it is used before and 
during reading. Before reading, it helps learners elicit purposes for reading and monitor comprehension. During reading, it helps students think critically about the reading texts, identify relevant information (Aloqaili, 2001).

\subsubsection{Questioning the Author}

It is a metacognitive strategy of inquiries that can be made about the content. Students can establish questions for the author about his or her intent for the selection of the reading text; such as, "Why is the author telling me that? Does the author say it clearly? etc." (McKeown \& Beck, 1999). This strategy was used during and after reading in this study. Questioning the author strategy was developed by Beck, McKeown, Sandora, Kucan, and Worthy (1996). This strategy differs significantly from other active engagement strategies; it helps students become actively immersed while reading. It does not only focus on having students scrabble about the meaning but it helps reflect on what an author is trying to tell and thus builds a representation from it. Taboada and Guthrie (2006) explained that higher-level question types; such as putting it together, author and you, and on your own will lead to deep processing of text as they are engaged in finding answers for them, and thus, result in higher comprehension.

\subsubsection{Making Connections Reading Strategy}

Schema theory explains how our previous experiences, knowledge, emotions, and understandings affect what and how we learn. Good readers draw on prior knowledge and experience to help them understand what they are reading through these connections. Thus, Harvey and Goudvis (2000) pointed out that students who are able to make these connections will better understand what they are reading. Harvey and Goudvis (2002) also asserted that accessing prior knowledge and experiences is a good starting place when teaching strategies because every student has experiences, knowledge, opinions, and emotions that s/he can draw upon.

The following notions are some of the reasons of why making connections strategy was used in this study:

- It enables readers have a clearer picture as they read which will make the reader more engaged.

- It keeps the reader from becoming bored during reading.

- It sets a purpose for reading and keeps the reader focused.

- It enables readers to see how other readers are connected to the reading.

- It forces readers to become actively involved.

- It helps readers remember what they have read and ask questions about the text.

\section{Research Methodology}

The purpose of this study is to investigate the effect of the cognitive and the metacognitive questioning strategies on EFL learners' reading comprehension in understanding, critical thinking and the quality of schema. Therefore, the variables of the study were as in the following:

a- The independent variable of the study is the teaching strategy at two levels: Questioning strategies and the current method.

b- The dependent variable is students' achievement in reading comprehension concerning the three selected skills: understanding, critical thinking and the quality of schema.

The sample of the study consisted of two sections: one experimental group that was taught according to the questioning strategies and one control group that was taught according to the current strategy. A schema-based test was adapted similar to the one used by Lewin (1992) to measure students' achievement before and after the experiment (See appendix G). The test consisted of questions that measure students' understanding, questions that measure students' critical thinking and questions that measure students' quality of schema (See appendix I). The researchers selected the reading material from the textbook used at the University of Hail in teaching (ENGL-160 Reading 1) in the second semester of the academic year 2018-2019. The reading texts selected were redesigned according to the questioning strategies in light of the five incorporated questioning strategies: KWL reading strategy, directed reading strategy, self-questioning reading strategy, questioning the author reading strategy and making connections reading strategy. To ensure the validity of the redesigned material and the schema-based test, they were given to a jury of English language instructors. The members of the jury were asked to carefully read the redesigned material and to record their comments and suggestions. All relevant comments and suggestions were taken into consideration when writing the final draft. The researchers used the quasi-experimental design with one experimental group and one control group with pre-post-test. At the end of the experiment, students were expected to: 
1) Increase their understanding of a variety of simple authentic texts (e.g., magazine and newspaper articles, advertisements, brochures, resource materials reports ... etc.).

3) Go beyond the text through thinking critically and using some of metacognitive strategies.

4) Use their prior knowledge to understand the text.

5) Implement the questioning reading strategies in the classroom reading lessons.

6) Create connections between concepts to comprehend.

\subsection{Implementation of the Teaching Material}

The researchers held two classes with one hour each with the two sections that were used in the experiment before starting the implementation of the teaching material to explain to the students the main objectives of the study and to discuss any related issues. In the classes, the researchers presented a model of how to carry out a reading lesson using this reading strategy with the incorporated strategies. These classes were given by the researchers to enlighten the students who were involved in the experimental group of the procedures of the reading strategy. The researchers chose an unseen reading text for training the students. This text was redesigned according to the questioning strategy used in this study. Although the instrument (schema-based reading test) used in this study was adapted from a reliable instrument, with additional items, a pilot study was conducted to ensure the reliability of the test. The reliability then was computed using Cronbach Alpha and the inter-rater reliability. The result on Cronbach Alpha was found to be (0.83). Students' test papers were corrected two times. After that, the reliability was computed using inter-rater reliability statistical analysis. The overall result was (0.93). The reliability coefficient for the instrument used in this study showed that the study instrument was satisfactorily reliable.

The researcher used five questioning reading strategies. The strategies were distributed to the three reading phases: before, while, and after. The strategies used were the following:

1) KWL

2) Directed reading.

3) Self-questioning.

4) Questioning the author.

5) Making connections (text-to life, text-to text, text-to world).

Each strategy was modeled based on the reading material used in the study and they were taught in an integrated way. To analyze the results of the reading test, the researchers used t-test, means and standard deviations.

3.1.1 Sample of a Reading Text Taught by the Five Questioning Strategies:

\section{Living in the USA}

The people of the United States are nearly all immigrants, or descendants of immigrants. But how do they find the US when they first arrive? What do they think of the people, the culture, the way of life? Jamie Peterson spoke to three of them.

Aziz Tounsi came from Tunis to New York ten years ago. He wanted to study English here. At first, he missed everything-the sunshine, the food, his family. But now he has a successful business with his three brothers and his wife. They run a sports store in New Brunswick. Aziz's wife is also Tunisian, and they have two children who go to American schools.

When asked about the future, Aziz says without hesitation 'I want to work hard and be successful.' He certainly works hard. He's at the store all day, then works as a driver in the evening. 'I like living here,' he says. 'You can be what you want. When I first came here, I didn't speak the language, and it was winter. It was so cold! There was snow! Now nearly all my family are here. We meet about once a month and have a huge Tunisian family meal! We' re all happy here.

Endre is a mathematician at Rutgers University, New Jersey. He came from Budapest thirteen years ago. 'I had an opportunity to come here for two years.' After a year, his wife came to join him, and since then they've had a daughter, so they decided to stay.

At first it was very strange. Everything is so big here, he says. I started to feel happy when I bought a car. Now I go everywhere by car. How does he find the people? very friendly. 'I like the fact that there are people from all over the world.' What about the way of life? The thing I like best is the independence. Here you can do what you want, so you learn to make decisions for yourself. 'I feel in control.' 
Yuet Tung is her Chinese name, but in English she is known Clara. She came to the US eight years ago and studied fine art. Now she works on Madison Avenue for a publisher. She married a Vietnamese American three years ago, and they live in Long Island. They don't have any children yet. What does she think of living in New York?' 'It is very similar to Hong Kong.' It is a busy city, very exciting, and people walk very fast! I like the stores here. What does she like best? The space. Here I live in a house with a yard and the people are friendly. And the food is from every country in the world.

\section{Before you read}

\section{KWL}

The researcher asked students to have a quick look at the title "Living in the USA" and the pictures involved and then asked them to fill in the first two columns of KWL chart (See Appendix A). The third column is left without completing in this stage.

\section{Guided Questions}

Before reading, the researcher asks students pre-reading questions about the main topic. The questions are as in the following:

1) What do you expect the text to tell you about?

3) Why do you think the writer choose USA to talk about?

4) Have you ever heard of similar title? What is it?

6) In light of the title, how do you describe the USA nowadays?

7) How do you predict the future of the USA?

8) How does living in the USA affect people's:

- way of life?

- way of thinking?

9) What other things do you expect the text to tell you about?

\section{Self-Questioning}

- The researcher asked students to write in the self-questioning reading strategy worksheet (See Appendix B) all the questions that come to their minds about the title, the topic. For example, they can ask:

1) Does the title make sense to me? How?

2) What does living in the USA mean to you?

3) What are some of the advantages of living in the USA?

\section{While you read}

\section{Guided reading strategy}

- The researcher asked students to have a quick look at the content of the text; the main purpose is to introduce the key vocabulary items to help them in discussion:

"Hesitation", "run", “opportunity", "Independence", “Avenue" ... etc.

1) The researcher then asked students to read the text silently to look for the specific details to answer the text-based questions. Below are some of the guided questions that deepen students' understanding of the content:

1) What do people have in common?

2) Are they all happy living in the USA?

3) What do they say about their own country?

4) What do they say about Americans and their cars?

5) What would you miss if you lived abroad?

Note: students were supposed to write their names on every worksheet they take.

Note: The researcher took all the incomplete worksheets to keep with for the next class to be continued.

- First, the researcher reminded students with the topic and of what they had started with before the end of the previous meeting. 
- Second, the researcher then distributed the worksheets with the names written on to the students.

- The researcher referred back to KWL and the Self-Questioning strategies and asked students to read silently the text for the second time and while reading, students were supposed to:

a. complete the third column of the KWL (Worksheet A)

b. write the possible answers in the self-questioning worksheet for the questions they generate in Before they read stage (Appendix B).

- The researcher again got the worksheets back and chose some of them to discuss with students. In this stage students were asked to think aloud and to say whatever comes to their minds in regard to the topic and to some points of their life that are related in one way or another to the topic.

\section{After You Read}

\section{Questioning the author}

- In this stage, students have got clear idea about the content of the text; therefore, the researcher then asked students to fill in the questioning the author worksheet (See Appendix C).

- But before, the researcher clarified the purpose of this strategy. It is to help students think critically, think beyond the reading lines, discover the message that the author wants to convey, search for the theme that the author wants us to learn and discover the weak points of the author. In this way, students will activate their existing knowledge (schemata), deepen their understanding, construct meaning and thus increase their reading comprehension.

- The researcher got questioning the author worksheets back and discussed some of them with the students.

- The researcher asked students again to have a quick look at the content not to remind them of what the lesson was but to make their own connections. This is because students in this stage have their new existing knowledge already stored in their minds throughout the strategies used in this study.

\section{Making Connections}

- After all, and in order to keep students' schemata activated, students in this stage were invited to fill in the making connections worksheets. There were three worksheets for this strategy (See Appendix D, E, and F).

1) Self-to-text connections in which students were supposed to make connections between the reading text they read "Living in the USA" and their own life (Appendix D).

2) Text-to-text connections in which students were invited to make connections between the reading text "Living in the USA" and the other texts or books they already read before (Appendix E).

3) Text-to-world connections in which students were asked to make connections between the reading text and the real world (Appendix F).

- The researcher got the worksheets back, chose and discussed some of them with the students.

- To investigate the students' appreciation of the reading text, the researcher asked students some of the questions as in the following:

1) What attracts you most in the text?

2) Does this topic make sense to you?

3) What do you think the author wants to tell you?

4) Summarize the major ideas in the text?

Note: the researcher gave each student hard copies of worksheets to fill individually (because each student has different schemata from others) in the appropriate time to avoid distraction and to keep them alert to every step the teacher follows.

\section{Evaluation Procedures:}

- Students' performance on the worksheets.

- The researcher's and the students' feedback.

\section{Findings of the Study}

To find out whether there were statistically significant differences in Pre-test due to group variable, t-test analysis was conducted and the results are shown in Table 1. 
Table 1.T-test results of PRE-TEST due to group variable

\begin{tabular}{llllllll}
\hline & GROUP & N & Mean & Std. Deviation & t & df & Sig. \\
\hline Understanding pre & Experimental & 36 & 11.14 & 2.320 & .858 & 71 & .394 \\
& Control & 37 & 10.62 & 2.802 & & & \\
Critical Thinking pre & Experimental & 36 & 10.67 & 2.928 & -.524 & 71 & .602 \\
& Control & 37 & 11.00 & 2.494 & & & \\
Quality of schema pre & Experimental & 36 & 10.36 & 2.880 & .486 & 71 & .628 \\
& Control & 37 & 10.00 & 3.432 & & & \\
PRE (total) & Experimental & 36 & 32.17 & 5.310 & .479 & 71 & .633 \\
& Control & 37 & 31.62 & 4.374 & & & \\
\hline
\end{tabular}

Table 1 depicts the mean scores and the standard deviations of the groups of the study on the pre-test according to the variables of the study. The results indicated that there were no statistically significant differences at $(\alpha=0.05)$ on pre-tests due to the group variable.

From the table above, it can be concluded that the experimental group and the control group were almost the same in the mean scores on the variables of the study before the treatment.

To find out whether there were statistically significant differences on the post-test due to group variables, t-test analysis was conducted and the results are shown in Table 2.

Table 2. T-test results of POST-TEST due to group variable

\begin{tabular}{llllllll}
\hline & Method & N & Mean & Std. Deviation & t & df & Sig. \\
\hline Understanding post & Experimental & 36 & 17.06 & 2.042 & 5.089 & 71 & .000 \\
& Control & 37 & 14.38 & 2.431 & & & \\
Critical Thinking post & Experimental & 36 & 15.25 & 2.534 & 4.870 & 71 & .000 \\
& Control & 37 & 12.70 & 1.898 & & & \\
Quality of schema post & Experimental & 36 & 16.67 & 2.255 & 4.686 & 71 & .000 \\
& Control & 37 & 13.78 & 2.945 & & & \\
POST (total) & Experimental & 36 & 48.97 & 3.953 & 8.593 & 71 & .000 \\
& Control & 37 & 40.86 & 4.104 & & & \\
\hline
\end{tabular}

Table 2 depicts the mean scores and the standard deviations of the two groups of the study on the post-test according to the variables of the study. The mean scores of the experimental group of the study were $(17.06,15.25$, $16.67)$ with standard deviations $(2.042,2.534,2.255)$ respectively. On the other hand, the mean scores of the control group on the three variables of the study were $(14.38,12.70,13.78)$ with standard deviations $(2.431,1.898$, $2.945)$ respectively. The results indicated that there were statistically significant differences at $(\alpha=0.05)$ on the post-test due to the groups variables in favor of experimental group after the treatment.

\section{Discussion of Findings}

The present study aimed to find out how the implementation of the cognitive and the metacognitive questioning strategies enhanced the students' reading comprehension in the three sub-skills of reading: understanding, critical thinking and the quality of schema. And thus, the current study aimed to test the following hypothesis:

There are no statistically significant differences in students' reading comprehension between the experimental group which was taught by the cognitive and the metacognitive questioning strategies and the control group which was taught by the conventional strategy in understanding, critical thinking and the quality of schema. The research hypothesis was tested by using t-test. The data of this study were taken from the result of pretest and posttest. The test assigned the students to show their ability to develop their skills in three sub-skills of reading comprehension. The results of the test were analyzed by assessing the three skills. The total score was 20 . The results on the pre-test indicated that the experimental group and the control group were almost the same in the mean scores on the variables of the study. On the other hand, the post-test showed that the mean scores of the two groups on the variables of the study differ in favor of the experimental group. The results clearly showed that the experimental groups' mean scores were better than the control's in the three sub-skills; and that the differences were significant at ( $\alpha=.05$ ) level of significance. Although the effect was not very high but it can be considered as an indicator of a change in students' reading comprehension. Therefore, further research is needed. It is expected that by having such kind of research, the effectiveness of using the cognitive and the metacognitive questioning strategies can be more explored. 
It is clear that the students who studied the reading comprehension texts based on the cognitive and the metacognitive questioning strategies performed better than the students who studied the material following the instructions in the textbook. This result is supported by the findings of the studies reviewed in the present study such as Bernadowski (2006); Sencebaugh and Sencebaugh (2015); Lewis (2015). These studies showed that there was a correlation between cognitive and metacognitive questioning strategies and students' comprehension.

The present study is based on schema theory which proposes that readers' prior knowledge directly impacts new learning situations; and reading comprehension implies an interaction between the readers' background knowledge and the text itself. In order to enable learners to effectively process information, their existing schemata related to the new content need to be activated. The result may be due to the schema activation procedure done by the researcher which is necessary to improve their reading comprehension in the three sub-skills as ascertained by Therrien and Hughes (2008); Boulware-Gooden, Carreker, Thornhill, and Joshi (2007); Taboada and Guthrie (2006) and Rowe and Rayford (2003).

Regarding the understanding skill, it is possible that having students wondering about a topic in a text and asking questions in relation to the topic contribute to active processing of the text; and thus, deeper understanding and higher number of inferences are expected. The result is supported by Ormrod (2008); Van den Broek, Tzeng, Risden, Trabasso, and Basche (2001) and Davis and Linn (2000).The improvement in students' understanding sub-skill may be due also to the nature of the questioning strategy as an important comprehension fostering strategy that can be easily implemented before, during and after reading. The questioning strategy was used before students read to activate prior knowledge, make predictions, and wonder about the main ideas that are not answered in the text. During reading, students were asked to form questions to compare and generalize, identify the theme, and clarify meaning; all may help deepen one's understanding and enjoyment of the text. After reading, students used questioning to locate information, understand and remember events and characters, make connections, and identify the theme. Questions were about clarifying the meaning of a phrase or passage, exploring important themes, considering the author's technique and way of writing, or learning more about something they find interesting.

Regarding the critical thinking skill, EFL learners got the second highest mean score compared with the other two intended skills. The result indicates its effectiveness in improving students' reading comprehension. This result may be due to the use of different cognitive and metacognitive reading strategies used at different stages of the reading process. These strategies were KWL, self-questioning and questioning the author. The effectiveness of these strategies has been emphasized by Rouse (2014) and Feng (2013) who reached the conclusion that these strategies have a metacognitive nature that help students think critically about the reading texts while they are reading for certain reasons. First, they help establish purposes for reading. Second, they help identify relevant information. Third, they help monitor comprehension; first, by realizing that they have questions, and second, by perceiving when their questions are answered and when they are not.

In the present study, as students read, they were asked to develop questions for the author's intent for the selection and his or her success at communicating it; such as, "Why is the author telling me that? Does the author say it clearly? How might the author have written it more clearly? What would you have wanted to say instead? Does the author seem biased in his way of writing and the examples he provides?" All the aforementioned questions invited students to read and to think critically of what they read and not to take everything for granted because authors are humans, so they cannot touch perfection. And, there are always ways better than what is written. The reviewed literature indicated that it is highly probable that higher-level question types (i.e., putting it together, author and you, and on your own) will result in deeper processing of text because of the processes involved in answering them (Bernadowski, 2006; Taboada \& Guthrie, 2006). In this study, the researcher used questioning the author strategy to have students grapple with and reflect on what an author is trying to say in order to build a representation from it.

This study also indicated that questioning the author strategy deemed effective in improving students' critical thinking through focusing their attention on the problem-solving processes. This result has been emphasized by Marzuki, Alim and Wekke (2017); Samelian (2017); Rashid and Qaisar (2016); Lewis (2015). The results of these studies indicated that this kind of questioning implies to focus their attention on the important elements and ideas in the text before and while reading. It helps students think about the problem in new ways, access prior knowledge and strategies, formulate and provide explanations to the problem, and monitor their progress. Thereby it promotes their reading comprehension.

Accordingly, the results of the present study indicated the importance of teaching students' critical thinking skills by using cognitive and metacognitive strategies at the university level. It was investigated that critical 
thinking skills are needed for successful undergraduate study within and across academic disciplines. Overall, the skills rated as most important were the abilities to question, explain ideas with reasonable clarity, to critically reflect on and analyze all information presented, to assemble facts to determine the validity of an argument, and to draw sound inferences from the information formed or given.

Comparing the control group's achievement in the quality of schema sub-skill with the experimental group's, the result indicated that the questioning group outperformed the control group. In the present study, the quality of schema means the way students represent their ideas and create connections between these ideas. This skill was taught through the use of the metacognitive strategy called making connections strategy which includes three types of connections: text-to-self, text-to-text and text-to-world. In these types of connections, students were supposed to use their background knowledge to fill in the worksheet. It was claimed that enabling students to make connections to their lives and the outside world helps activate their schemata and thus their reading comprehension.

Widmayer (2002) demonstrated that the important concept in understanding cognitive responses is patterns of association. This phrase summarizes the observation that an individual's response to a particular context or situation is a chain of related responses or items. These items are not rigidly controlled or predictable, but depend on both the external context and the individual's internal mental state. Since the latter is not directly observable, the associations were treated as probabilistic. He concluded that the pattern of association may be strong if a link is activated in a large variety of situations or weak if a link is rarely activated. Patterns of associations may contain any type of knowledge (i.e., facts, formulas, concepts, rules, etc.).

It can be concluded that schemata are important not just in interpreting information, but also in decoding how that information is presented. The importance of schema-activation can be seen in the fact that "Stimulating Recall of Prior Knowledge" is the third stage in Gagne's nine events (Gagne \& Glaser, 1987). In conclusion, it is important to recognize that cognitive and metacognitive questioning strategies can be used to facilitate learning, or can be used to facilitate comprehension. And, mastering various reading strategies can develop readers' reading skills at their different academic levels.

\section{Recommendations}

Based upon the findings of the current study, it is recommended that more studies should be conducted to investigate other metacognitive strategies to determine the most appropriate and effective ones in enhancing university students' reading comprehension. The studies can be conducted on both narrative and expository texts to have the most instructional value for each type of text.

\section{Acknowledgement}

The authors would like to thank the University of Hail represented by the deanship of the scientific research for funding this project under research grant number (160874).

\section{References}

Ajideh, P. (2003). Schema Theory-Based Pre-Reading Tasks: A Neglected Essential in the ESL Reading Class. The Reading Matrix, 3(1), 3-12.

Aloqaili, A. (2001). Perceptions of Saudi Arabian Reading Teachers of Selected Concepts Related to Schema Theory. Unpublished Ph.D. Faculty of the College of Education. Ohio University.

Beck, I., McKeown, M., Sandora, C., Kucan, L., \& Worthy, J. (1996). Questioning the Author: A Yearlong Classroom Implementation to Engage Students with Text. Elementary School Journal, 96, 385-414. https://doi.org/10.1086/461835

Becky, L. (1989). Reading and Reasoning. The Reading Teacher, 42, 676-682.

Bernadowski, C. (2006). The Effect of Teachers' Questioning Patterns on Learners Outcomes. Unpublished Ph.D. The University of Pittsburgh. Retrieved January 6, 2010 from http://www.proquest.com

Bonds, C., Grant Bonds, L., \& Peach, W. (1992). Metacognition: Developing Independence in Learning. Clearing House, 66(1), 56-59. https://doi.org/10.1080/00098655.1992.9955930

Boulware-Gooden, R., Carreker, S., Thornhill, A., \& Joshi, R. (2007). Instruction of Metacognitive Strategies Enhances Reading Comprehension and Vocabulary Achievement of Third-Grade Students. The Reading Teacher, 61, 70-77. https://doi.org/10.1598/RT.61.1.7

Bransford, J., Brown, A., \& Cocking, R. (Eds.). (1999). How People Learn: Brain, Mind, Experience, and School. Washington, D.C.: National Academy Press. 
Broek, P., \& Kremer, K. (2000). The Mind in Action: What It Means to Comprehend during Reading. In B. Taylor, M. Graves \& P. Broek (Eds.), Reading for Meaning: Fostering Comprehension in the Middle Grades (pp. 131). Newark. DE: International Reading Association.

Byrne, G. (2011). Using Socratic circles to develop critical thinking skills. Practically Primary, 16(2), 13-15.

Crane, L., Poziemski, C., \& Gustafson, J. (1998). Assessing Motivational Aspects of Reading in Reading Developmental Courses. A Paper Presented at the Annual Meeting of the Illinoise Association for Institutional Research, Findlay, IL.

Davis, E., \& Linn, M. (2000). Scaffolding Students' Knowledge Integration: Prompts for Reflection in KIE. International Journal of Science Education, 22, 819-837. https://doi.org/10.1080/095006900412293

Devine, J. (1993). The Role of Metacognition in Second Language Reading and Writing. In J. Carson \& I. Leki (Eds.), Reading in the Composition Classroom: Second Language Perspectives (pp. 105-127). Boston: Heinle and Heinle.

Devine, T. (1986). Teaching Reading Comprehension: From Theory to Practice. Massachusetts: Allyn and Bacon.

Dole, I., Duffy, G., Roehler, L., \& Pearson, P. (1991). Moving from the Old to the New: Research on Reading Comprehension Instruction. Review of Educational Research, 61, 239-264. https://doi.org/10.3102/00346543061002239

Eggen, P., \& Kaucbak, D. (1995). Strategies for Teachers: Teaching Content and Thinking Skills. Boston: Allyn and Bacon.

Feng, Z. (2013). Using Teacher Questions to Enhance EFL Students' Critical Thinking Ability. Journal of Curriculum and Teaching, 2(2), 147-153. https://doi.org/10.5430/jct.v2n2p147

Francois, J. (2016). The impact of teacher prompting and questioning on third grade students' comprehension (p. 216). Honors Program Theses. Retrieved April 12, 2017 from http://scholarworks.uni.edu/hpt/216

Garb, E. (2000). Maximizing the Potential of Young Adults with Visual Impairments: The Metacognitive Element. Journal of Visual Impairment and Blindness, 94(9), 574-583. https://doi.org/10.1177/0145482X0009400904

Harvey, R., \& Goudvis, A. (2002). Strategies that Work: A Reader with No Questions Might just as well Abandon the Book. Journal of the Education Development Department Center. Retrieved June 5, 2008, from http://www.literacymatters.org/help.htm

Hazzard, K. (2016). The Effects of read aloud on student comprehension (p. 351). Education Masters. Retrieved February 10, 2017 from http://fisherpub.sjfc.edu/education_ETD_masters/351

Hoyt, J., \& Sorenson, C. (2001). High School Preparation, Placement Testing, and College Remediation. Journal of Developmental Education, 25(2), 26-33.

Iannelli, A. (2016). The effects on student understanding when questioning techniques are used during the reading of informational text (p. 574). Theses and Dissertations.

Kendeou, P. (2014). A cognitive view of reading comprehension: Implications for reading difficulties. Learning Disabilities Research \& Practice, 29(1), 10-16. https://doi.org/10.1111/ldrp.12025

Kirschner, P., Sweller, J., \& Clark, R. (2006). Why Minimal Guidance during Instruction Does Not Work: An Analysis of the Failure of Constructivist, Discovery, Problem-Based, Experiential, and Inquiry-Based Teaching. Educational Psychologist, 41(2), 75-86. https://doi.org/10.1207/s15326985ep4102_1

Lewin, B. (1992). A Schema-Based Reading Test. A Paper Presented at the Trilingual Conference in Israel. ERIC Document, ED361675. Retrieved September 22, 2008, from http://www.eric.ed.gov/ERICDocs/data/ericdocs2sq1/content_storage_01/0000019b/80/13/13/1a.pdf

Lewis, K. (2015). Developing questioning skills. Retrieved from https://inside.trinity.edu/sites/inside.trinity.edu/files/fileattachments/6056/gravett-questioningskillswithattac hment.pdf

Marshall, S. (1995). Schemas in Problem Solving. NY: Cambridge University Press. https://doi.org/10.1017/CBO9780511527890

Marzuki1, A., Alim, N., \& Wekke, I. (2017). Improving the reading comprehension through cognitive reading strategies in language class of coastal area in Indonesia. IOP Conf. Series: Earth and Environmental Science 156 (2018) 012050. https://doi.org/10.1088/1755-1315/156/1/012050 
Mayer, R. (2004). Should There Be a Three-Strikes Rule Against Pure Discovery Learning? The Case for Guided Methods of Instruction. American Psychologist, 59(1), 14-19. https://doi.org/10.1037/0003-066X.59.1.14

McCollister, K., \& Sayler, M. (2010). Lift the ceiling: Increase rigor with critical thinking skills. Gifted Child Today, 33(1), 41-47. https://doi.org/10.1177/107621751003300110

McKeown, M., \& Beck, I. (1999). Getting the Discussion Started. Educational Leadership, 57(3), 25-28.

Memiş, A., \& Bozkurt, M. (2013). The relationship of reading comprehension success with metacognitive awareness, motivation, and reading levels of fifth grade students. Global Journal of Educational Foundation, $1(1), 34-38$.

Morgan, N., \& Saxton, J. (2001). Asking Better Questions: Models, Techniques and Classroom Activities for Engaging Students in Learning. Ontario: Pembroke

Nappi, J. S. (2017). The Importance of Questioning in Developing Critical Thinking Skills. International Journal for Professional Educators, 84(1), 30-41.

Norris, S., \& Phillips, L. (1987). Explanations of Reading Comprehension: Schema Theory and Critical Thinking Theory. Teachers College Record, 89(2), 281-306.

Ormrod, J. (2008). Human Learning (5th ed.). Upper Saddle River, NJ: Pearson/Merrill. Prentice Hall.

Peterson, D. S., \& Taylor, B. M. (2012). Using higher order questioning to accelerate students' growth in reading. The Reading Teacher, 65(5), 295. https://doi.org/10.1002/TRTR.01045

Peverly, S., Brobst, K., \& Morris, K. (2002). The Contribution of Reading Comprehension Ability and Meta-Cognitive Control to the Development of Studying in Adolescence. Journal of Research in Reading, 25(2), 203-216. https://doi.org/10.1111/1467-9817.00169

Rashid, S., \& Qaisar, S. (2016). Developing Critical Thinking through Questioning Strategy among Fourth Grade Students. Bulletin of Education and Research, 38(2), 153-168

Rouse, C. (2014). The Effects of a Self-Questioning Strategy on the Comprehension of Expository Passages be Elementary Students Who Struggle with Reading. Unpublished Ph.D. The Ohio State University. Retrieved January 6, 2019 from https://etd.ohiolink.edu/!etd.send_file?accession=osu1404822444\&disposition=inline

Ruggiero, V. (1984). The Art of Thinking: A Guide to Critical and Creative Thought. New York: Harperand Row.

Rumelhart, D. (1980). Schemata: The Building Blocks of Cognition. In R. Spiro, B. Bruce \& W. Brewer (Eds.), Theoretical Issues in Reading Comprehension (pp. 33-58). Hillsdale, NJ: Erlbaum. https://doi.org/10.4324/9781315107493-4

Samelian, L. A. (2017). How Higher Order Questioning and Critical Thinking Affects Reading Comprehension. School of Education Student Capstone Theses and Dissertations, 43-45. Retrieved from https://digitalcommons.hamline.edu/hse_all/4345

Sencebaugh, J., \& Sencebaugh, M. (2015). The Effects of Questioning the Author on the Reading Comprehension of Middle School Students. Reading Improvement, 52(3), 85-92.

Taboada, A., \& Guthrie, J. (2006). Contributions of Student Questioning and Prior Knowledge to Construction of Knowledge from Reading Information Text. Journal of Literacy Research. https://doi.org/10.1207/s15548430jlr3801_1

Therrien, W., \& Hughes, C. (2008). Comparison of Repeated Reading and Question Generation on Students' Reading Fluency and Comprehension. Learning Disabilities, A Contemporary, 6(1), 1-16.

Tierney, R., \& Readence, J. (2000). Reading Strategies and Practices (5th ed.). Needham Heights, MA: Allen and Bacon.

Usman, B., Aziz, Z., \& Absidai, N. (2017). Improving Reading Comprehension Using Metacognitive Strategies. English Education Journal, 8(4), 425-438.

Van Den Broek, P., Tzeng, Y., Risden, K., Trabasso, T., \& Basche, P. (2001). Inferential Questioning: Effects on Comprehension of Narrative Texts as a Function of Grade and Timing. Journal of Educational Psychology, 93, 521-529. https://doi.org/10.1037/0022-0663.93.3.521

Von Bertalanffy, L. (1962). General system theory-A Critical Review. General Systems, 7, 1-20.

Widmayer, S. (2002). Schema Theory: An Introduction. Unpublished Ph.D. George Mason University.

Yang, Y. (2002). Reassessing Readers' Compression Monitoring. Reading in a Foreign Language, 14(1). 


\section{Notes}

Dr. Lina A. Salameh, Associate Professor and a certified trainer by IBCT, earned her PhD in Curriculum and Methods of English Language Teaching from Yarmouk University in Jordan. She taught courses in language teaching at the University of Jordan and moved to the University of Hail, KSA, where she is currently teaching. Her research interests include finding new ways and visions in the field of English language teaching and learning. She has international publications in this field.

Dr. Zakariya A. Salameh finished PhD in Educational technology in 2012, was granted USM fellowship during $\mathrm{PhD}$ study and was awarded the certificate of excellence in writing research papers by USM. Currently, he is working as Assistant Professor in the college of arts at University of Hail, KSA. He is a certified trainer by the IBCT.

Dr. Aida H. Al-Emami has a PhD in Curriculum and Methods of English Language Teaching from Yarmouk University. She is a certified trainer in ICDL, INTEL, Thinking Tools and Education Reform Support Program (ERSP). In addition, she has attended several intensive training courses and seminars in teaching strategies, assessment strategies, training teachers, classroom management and individual differences. She is currently an Assistant Professor at the University of Hail, KSA.

\section{Appendix A}

\section{Worksheet (KWL)}

Student's Name:

Title of the text:

\begin{tabular}{lll}
\hline What I know about the topic $(\mathrm{K})$ & What I want to know about the topic $(\mathrm{W})$ & What I learned (L) \\
\hline
\end{tabular}

\section{Appendix B}

\section{Worksheet (Self-Questioning)}

Student's Name:

Title of the text:

Before you read, write down the questions you would like to ask yourself about the title, the pictures involved.... etc., while reading, write down the possible answers to your questions.

The Self-Questions (before reading) The possible answers (while reading)

\section{Appendix C}

\section{Worksheet (Questioning the Author)}

Student's Name:

Title of the text

Questioning the author strategy (During reading activity/ fill on the following rows depending on the text What is the author trying to tell me?

Is it said clearly?

How might the author have written it more clearly?

What would you have wanted to say instead?

\section{Appendix D}

\section{Worksheet (Self-to-text Connections)}

Student's Name:

Title of the text:

Author's name: 
After reading the text, write about how the text is similar or different from your own life by using the questions in the chart.

\begin{tabular}{ll}
\hline In the text & In my life \\
\hline Discuss what is happening in the text you are reading. & What does this remind me of in my life? \\
& What is this similar to in my life? \\
& How is this different from my life? \\
\hline
\end{tabular}

\section{Appendix E}

\section{Worksheet (Text-to-text Connections)}

Student's Name:

Title of the text:

Author's Name:

After reading the text, compare how it is similar and different to another text or book have read by using the questions in the chart

\begin{tabular}{ll}
\hline In the text & In another text or book \\
\hline Discuss what is happening in the book you are reading. & What does this remind me of in another text or book I have read? \\
& How is this similar to other texts or books I've read? \\
& How is this different from other texts or books I have read? \\
\hline
\end{tabular}

\section{Appendix F}

\section{Worksheet (Text-to-World Connections)}

Student's Name:

Title of the text:

Author's Name:

After reading a book or piece of text, compare how the book is similar and different to the world around you by using the questions in the chart.

\begin{tabular}{ll}
\hline In the text & In the World \\
\hline Discuss what is happening in the text you are reading. & What does this remind me of in the real world? \\
& What is this similar to things that happen in the real world? \\
& How is this different from things that happen in the real world? \\
\hline
\end{tabular}

\section{Appendix G}

Pre-post Schema-based reading test

\section{Kingdom of Saudi Arabia \\ Ministry of Education \\ University of Hail \\ Faculty of Arts}

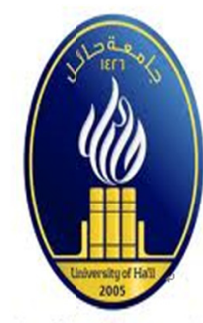

جـامـعـة حـأسلـل

Universitu of Ha'il

\section{Department of English Schema-based test ENGL- 160}

Time: Two hours

\section{Student's Name:}

ID: 


\section{Read the following article carefully then answer the following questions:}

(A) A beginning from the earliest sledges, people have sought ways to move themselves, messages and goods from place to place. By 1900, speeds of up to 120 miles per hour were possible on land. The spread of steamships, the introduction of railways and the development of bicycles were among the transforming innovations of the 19th century. The scope of transportation in industrial countries was further widened in the 20th century with the mass production of the automobile and the development of air travel.

(B) Since the end of the World War Two, motor vehicle production has risen almost linearly. As a result, the global car fleet now numbers more than 500 million in the United States, the number of household vehicles increase at sometimes the rate of the population between 1969 and 1995. However, while road traffic dominates the transportation system, air transportation is the fastest growing segment. And as road and air travel have grown, rail has become relatively less important.

(C) Cities have spread out over larger expanses of land as builders have constructed wide expressways and wide ample parking to accommodate motor vehicles. Asked in a survey to identify the top influence shaping the American metropolis, a sampling of urban historians, social scientists and architects chose the highway system and dominance of the automobile as the number-one influence. And as cities sprawl, cars become essential while transit, bicycling and walking become less practical. In the Czech Republic, for instance, car use has surged and public transit use has fallen as the number of suburban hypermarkets ballooned from one to fifty-three between 19997 and 2000.

(D)Advances in transport technology have brought benefits, but growing vehicle fleets and escalating fuel use have also created problems. Researchers estimate that nearly a million people are killed on the roads each year, and most of them are pedestrians. Motor vehicle impede other forms of traffic and cause delays. Congested roads in Sao Paulo have prompted the wealthiest residents to take to the skies, boosting the city's helicopter fleet to the third largest in the world, after New York and Tokyo.

Roads also cause profound changes to ecosystems. A great deal of land in car-dependent cities is lost to roads and parking lots. Water quality and quantity both suffer in proportion to the amount of paved roads and parking that cover a watershed. Plants and animals are killed during road construction as well as by vehicles. And roads promote the dispersal of species that are not native to a given area, and alter the physical and chemical environment.

(E) The single largest contributor to the costs of transportation borne by society in many countries is illness and deaths from air pollution. One challenge, therefore, is to tackle immediate health threats from the most polluting vehicles. By adopting policies that promote cleaner technologies, governments can take one important step towards solving this problem.

(F)Today transportation planners increasingly recognize that building more roads does not necessarily solve traffic problems. Michael Replogle, a transportation specialist, came up with this analogy: "Adding highway capacity is like buying larger pants to deal with your weight problems." As new roads attract more cars. Measures to diversify transportation options include regulations to curb car traffic, price incentives to reduce motor vehicle use and boost alternatives and changes in urban design that enhance the viability of cycling, walking and public transit.

(G) Individuals make choices everyday about different transportation modes, based, in part, on perceptions about safety and comfort. Poorly maintained cycling and public transport networks are therefore less appealing than the private car. High-income residents of Mexico City, surveyed in a recent study of travel behavior, said they feared robberies on buses and that they would use public transportation only if it were safe, well organized and comfortable.

People are also influenced by the car's image of freedom, power and modernity. To many young people, getting a driver's license is a rite of passage. In one survey in England, young adults were asked: "Imagine that you were only able to have one of the following rights-the right to vote in an election, or the right to obtain a driving license-which would you choose?" Some seventy-two per cent chose the license.

(H) But views and behaviors may change, as congested roads thwart the car's promise of individual freedom and power. The category "traffic congestion and urban sprawl" was the major concern of both urban and suburban Americans, and nationwide it tied with "crime and violence" as the top worry according to five public-opinion surveys around the country.

(I) The automobile came to dominate the world's roads in the last century, the age of oil. Today, with environmental and social costs of traffic well documented, and with the natural gas and renewable sources of 
energy beginning to replace oil, we can envision a new generation transportation system. Vehicles could be cleaner, and cities could be made more attractive and functional, with integrated networks for bicycles, bus, rail and new types of transit. People will need to work together to build this future, and to confront those in government and industry with vested interests in transportation systems that belong to the last century.

\section{Question number one:}

The reading passage has nine sections labeled A-I. Write the appropriate letters A-I in the spaces below.

1) Which section describes the attraction of the car for young people?

2) Which section compares the growth of the population and car ownership?

3) Which section mentions energy sources which have advantages over oil?

4) Which section describes how expanding the road network has failed to reduce traffic congestion?

5) Which section mentions a city where the rich have begun commuting by air? ........

Question number two: Several of the verbs below come from the reading text. Decide whether the general meaning in each case is $A$ or $B$.

A. Become or make more, wider, or bigger.

B. Become or make less or smaller.

\begin{tabular}{|rrr|}
\hline Balloon & escalate & sprawl \\
& Boost & fall \\
& & spread \\
\hline
\end{tabular}

Question number three: What is the main problem discussed in the article?

Question number four: Why is this problem worse today? (Elicit the main reasons)

Question number five: What resulted from this problem (Elicit the effects)?

Question number six: What other solutions do you suggest to solve the problem?

Question number seven: Try to think of reasons for and against each point of view.

A. The world would be a better place without cars.

B. We should build more motorways.

C. Basic driving skills should be taught at school.

D. The minimum age for driving should be 25 .

Question number eight: Which of the following two statements represents the view of the author?

1) As the standard of life continues to grow, the number of vehicles will also increase and we can only expect the problem to get worse.

2) Even the number of vehicles continues to escalate, there is hope for finding alternatives that solve the problem properly.

Question number nine: What does the problem suggested in the text remind you of similar problem in your country?

\section{Copyrights}

Copyright for this article is retained by the author, with first publication rights granted to the journal.

This is an open-access article distributed under the terms and conditions of the Creative Commons Attribution license (http://creativecommons.org/licenses/by/4.0/). 